\title{
Production of hyaluronan and chondroitin sulphate proteoglycans from human arterial smooth muscle - the effect of glucose, insulin, IGF-I or growth hormone
}

\author{
Christian Erikstrup, Lene-Marie Pedersen, Lene Heickendorff ${ }^{2}$, Thomas Ledet and Lars M Rasmussen ${ }^{1}$ \\ Research Laboratory for Biochemical Pathology, ${ }^{1}$ Laboratory for Molecular Biology, Institute for Experimental Clinical Research, University of Aarhus, \\ Aarhus Kommunehospital and ${ }^{2}$ Department of Clinical Biochemistry, Aarhus Amtssygehus, Aarhus, Denmark \\ (Correspondence should be addressed to T Ledet, Research Laboratory for Biochemical Pathology, Building 3, Aarhus Kommunehospital, \\ DK-8000 Aarhus C, Denmark; Email: Ledet@biobase.dk)
}

\begin{abstract}
Background: Although it is recognized that the extracellular matrix is important for cell proliferation, migration and metabolism of growth factors, the regulation of the synthesis of hyaluronan and chondroitin sulphate proteoglycan (CSPG) in the vessel wall is poorly understood.

Objective: To examine the role of glucose, insulin, IGF-I and human growth hormone (hGH) on the accumulation of hyaluronan and CSPG using cultures of human aortic smooth muscle cells.

Methods: The cultures were exposed for $36 \mathrm{~h}$. The CSPG content in the incubation medium was measured by a combination of digestion with testicular hyaluronidase and precipitation of $\left[{ }^{35} \mathrm{SO}_{4}{ }^{2-}\right]$ labelled material with ethanol and trichloroacetic acid. Hyaluronan was estimated using a radiometric assay.

Results: Glucose and insulin reduced the amount of synthesized hyaluronan $(2 P<0.01)$. Stimulation of synthesis was seen with hGH $(2 P<0.01)$, whereas no effect was observed with IGF-I. The production of CSPG was increased with glucose and hGH $(2 P<0.01)$, but showed no change with insulin.

Conclusions: The present data obtained with human arterial smooth muscle cells in vitro showed that glucose, insulin and hGH can influence the accumulation of hyaluronan and CSPG. These observations may be relevant for an understanding of diabetic macroangiopathy.
\end{abstract}

European Journal of Endocrinology 145 193-198

\section{Introduction}

Proteoglycans occur both in the extracellular matrix and at the cell surface in the arterial wall (1). Matrix proteoglycans can be divided into three groups: those present in the basement membrane; the hyalectans, which contain lectin-like domains and interact with hyaluronan and various carbohydrates; the small leucine-rich proteoglycans (2). However, hyaluronan is not classified as a proteoglycan, but as a glycosaminoglycan without sulphate units.

The function of many of these compounds is poorly understood, but they seem to be important for a number of fundamental cellular processes such as cell migration (3), cell proliferation $(4,5)$, regulation of growth factors $(6,7)$, lipid binding (8), etc. Therefore, these vascular wall constituents may be expected to operate during the development of abnormalities in the vessels.

In this respect diabetes mellitus is of particular interest because it leads to development of an arterial disease that is a major threat to the health of the patients. The pathogenesis is unknown, but most studies have focused on the relationship between diabetes mellitus, abnormalities of serum lipids, and atherosclerosis. Little effort has been made to integrate the presence of a diabetic macroangiopathy into the development of atherosclerosis in diabetes mellitus. It is reasonable to take the concept of a diabetic macroangiopathy into consideration, as it is regarded as a part of the generalized diabetic angiopathy $(9,10)$. However, diabetic macroangiopathy, which is seen as a set of non-atherosclerotic changes in the vessel wall, is defined on the basis of morphological and biochemical criteria, albeit inchoate, rather than by clinical observations.

Tunica media in the coronary arteries and the aortas obtained from patients with diabetes mellitus contains more periodic acid-Schiff positive material, less glycosaminoglycans $(11,12)$, and more connective tissue, calcium (11, 13), fibronectin (14), type IV collagen (15) and hyaluronan (16) in areas without visible 
atherosclerosis than in corresponding regions from vessels taken from non-diabetic patients. What initiates the development of these changes is unknown, but the hypothesis of a diabetic macroangiopathy ascribes the vessel alterations to abnormalities of diabetic metabolism. Glucose, insulin, insulin-like growth factor (IGF)-I and human growth hormone (hGH) are obvious trigger candidates to be investigated. Because of the importance of chondroitin sulphate and hyaluronan, we have focused on the accumulation of these two substances using cultures of human arterial smooth muscle cells.

\section{Materials and methods}

The study was approved by the local ethics committee.

\section{Cells}

Human smooth muscle cells were established from explants $(2 \times 2 \mathrm{~mm})$ of tunica media from normal aortas of humans aged 35-45 years, and incubated in culture flasks (264 ml Nunc, Roskilde, Denmark) with standard growth medium (minimal essential medium with 5\% newborn calf serum and 5\% human serum) for 4-6 weeks (17). The cells were detached by trypsination, resuspended in standard growth medium, and incubated in culture flasks until they reached confluency. Third passage cells were used in the experiments.

\section{Experimental conditions}

The cell cultures were incubated for $36 \mathrm{~h}$ in either control medium (with $2.5 \%$ newborn calf serum and $2.5 \%$ human serum) or test medium (with 2.5\% newborn calf serum and $2.5 \%$ human serum) with fresh medium after the first 18-20 h. The various test substances included glucose at concentrations of 5.5 , $8.0,16,20$ and $30 \mathrm{mmol} / \mathrm{l}$; insulin was used in concentrations of 10, 50, 100, 200 and $1000 \mu \mathrm{U} / \mathrm{ml}$. Recombinant hGH was added at concentrations of 0.5 , 1.25, 5.0, 10 and $20 \mathrm{ng} / \mathrm{ml}$, and IGF-I was applied in concentrations of $0.6,6.0$ and $60 \mathrm{mmol} / \mathrm{l}$. As an osmotic control for the glucose experiment, $30 \mathrm{mmol} / \mathrm{l}$ mannitol was included.

\section{Measurements of chondroitin sulphate proteoglycan}

Sulphur-35-labelled sulphate $\left({ }^{35} \mathrm{SO}_{4}{ }^{2-}\right)$ was used in a concentration of $10 \mu \mathrm{Ci} / \mathrm{ml}$ (NEN, Boston, MA, USA) for estimating the rate of production of chondroitin sulphate proteoglycan (CSPG).

The medium was removed, dialysed and lyophilized. Resuspended proteoglycans were precipitated with $95 \%$ ethanol at $4{ }^{\circ} \mathrm{C}$, and then dissolved in $800 \mu \mathrm{l}$ $50 \mathrm{mmol} / \mathrm{l}$ sodium acetate, $\mathrm{pH}$ 5.0, and divided into two samples.

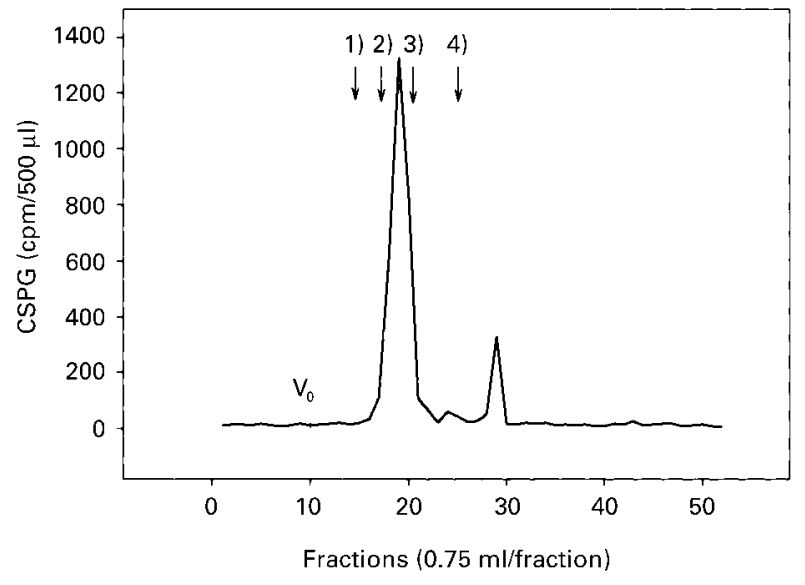

Figure 1 The pattern of elution of $\left[{ }^{35} \mathrm{SO}_{4}{ }^{2-}\right]$-labelled CSPG after degradation with testicular hyaluronidase using gel chromatography. CSPG was isolated from the medium of human aortic smooth muscle cultures. Standards were various carbohydrates: 1) maltoheptose (heptasaccharide), mol. wt 1153.0; 2) maltohexose (hexasaccharide), mol. wt 990.86; 3) maltopentose (pentasaccharide), mol. wt 828.72; 4) stachyose hydrate (tetrasaccharide), mol. wt 666.66. $\mathrm{V}_{0}=$ void volume.

CSPG was measured as radiolabelled tetra- and hexasaccharides after depolymerization with testicular hyaluronidase (Sigma type IV). The released chondroitin sulphate fragments were separated from larger molecules by precipitation with trichloroacetic acid. The radiolabelled chondroitin sulphate fragments present in the supernatant were counted in a liquid scintillation counter. The amount of CSPG was calculated as c.p.m. in the enzymatically degraded fraction.

For evaluation of the proteolytic activity of hyaluronidase, radiolabelled $\left(\left[{ }^{3} \mathrm{H}\right]\right.$ leucine $)$ cell material was used, and approximately $3 \%$ of the radioactivity was found in the enzymatically degraded fraction. In order to visualize the action of the hyaluronidase treatment on the sulphate-labelled medium, a high performance liquid chromatography analysis (HPLC, Perkin Elmer) was carried out on the degraded fraction using a Superdex 75 HR 10/30 column (Amersham Pharmacia Biotech) and a buffer of $100 \mathrm{mmol} / \mathrm{l} \mathrm{CH}_{3} \mathrm{COONH}_{4}$ with 7\% isopropyl alcohol at pH 5.0 (Fig. 1).

\section{Measurements of hyaluronan}

Hyaluronan was measured in medium from cultures that were not labelled, using a radiometric assay (HAtest, Pharmacia Diagnostics, Uppsala, Sweden) in accordance with the manufacturer's instructions. The medium was diluted 1:20 with phosphate-buffered saline (PBS) before analysis. Intra- and interassay coefficients of variation of $5.2 \%$ and $6.7 \%$ were obtained. Hyaluronan could not be detected in samples 
of test medium unexposed to cell cultures (undiluted samples).

\section{Measurements of DNA and protein}

The cell layer was rinsed twice in saline PBS. The DNA content was measured by fluorometry using bisbenzimide H33258 (Fluka) and calf thymus DNA as standard (Sigma) (18). The protein concentration was determined using bovine albumin as a standard (19).

\section{Statistical methods}

Each experiment consisted of groups of 10-28 confluent cell cultures. The results were calculated as c.p.m./ $\mu \mathrm{g}$ cell protein or DNA, and the data expressed as percent of control values. Statistical evaluation was performed with either ANOVA or the Mann-Whitney $U$-test. A $2 P$ value less than 0.05 was accepted as statistically significant.

\section{Results}

Hyaluronan was measured using a commercially available radiometric assay. The data showed that increased glucose concentrations resulted in a significantly reduced accumulation (ANOVA, $2 P<0.01$ ), as can be seen in Fig. 2. A dose-dependent decrease could also be observed when the cultures were supplemented with various amounts of insulin (ANOVA, $2 P<0.01$; Fig. 3). hGH stimulated the accumulation of hyaluronan in low concentrations, whereas greater amounts showed no effect (Fig. 4). It was not possible to demonstrate any effect of IGF-I on the concentration of hyaluronan (control: $100 \pm 18.0 \% ; 0.6 \mathrm{nmol} / \mathrm{l}$ IGF-I: $83.94 \pm 9.2 \%$; $6.0 \mathrm{nmol} / \mathrm{l}$ IGF-I: $90.1 \pm 9.7 \%$; $60 \mathrm{nmol} / \mathrm{l}$ IGF-I: $86.9 \pm 6.7 \%$ (means \pm S.E.M.)).

CSPG was quantified using a classic precipitation technique and enzymatic degradation with hyaluronidase (20). The accumulation of CSPG increased significantly after the addition of a high concentration of glucose ( $5.5 \mathrm{mmol} / \mathrm{l}$ glucose (control): $659.26 \pm$ 44 c.p.m. $/ \mu \mathrm{g}$ protein, $n=19 ; 20 \mathrm{mmol} / \mathrm{l}$ glucose: $1532.00 \pm 85$ c.p.m. $/ \mu \mathrm{g}$ protein, $n=9$ (means \pm S.E.M.); $2 P<0.01$ ). No effect of $15 \mathrm{mmol} / \mathrm{l}$ glucose was seen. The increase was not observed when the glucose was replaced by an equimolar concentration of mannitol ( $5.5 \mathrm{mmol} / \mathrm{l}$ glucose (control): $546.00 \pm$ 33 c.p.m. $/ \mu \mathrm{g}$ protein, $n=20 ; 30 \mathrm{mmol} / \mathrm{l}$ mannitol: $492.00 \pm 22$ c.p.m. $/ \mu \mathrm{g}$ protein, $n=15$; means \pm S.E.M.). The results obtained with various amounts of insulin revealed no change in the accumulation of CSPG, even with a concentration of $1000 \mu \mathrm{U} / \mathrm{ml}$, as seen in Fig. 5.

hGH significantly increased the concentration of CSPG (ANOVA, $2 P<0.01$ ). The effect of $10 \mathrm{ng} / \mathrm{ml}$ seemed to be the same as that of $5.0 \mathrm{ng} / \mathrm{ml}$ (Fig. 6).

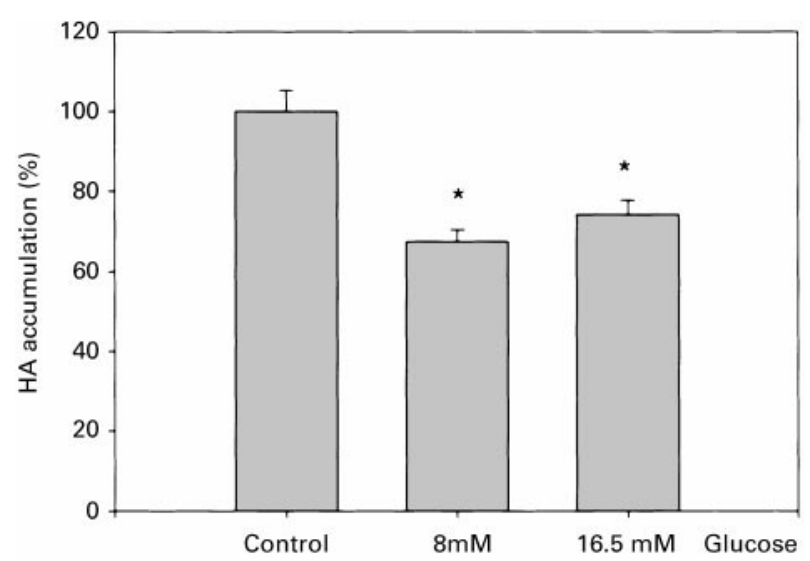

Figure 2 Effect of glucose on the accumulation of hyaluronan (HA) measured in the medium from cultures of human aortic smooth muscle cells after $36 \mathrm{~h}$ of incubation. Values are means \pm S.E.M. Number of cultures $=10-12$. Control was $5.5 \mathrm{mM}$. ${ }^{*} 2 P<0.01$.

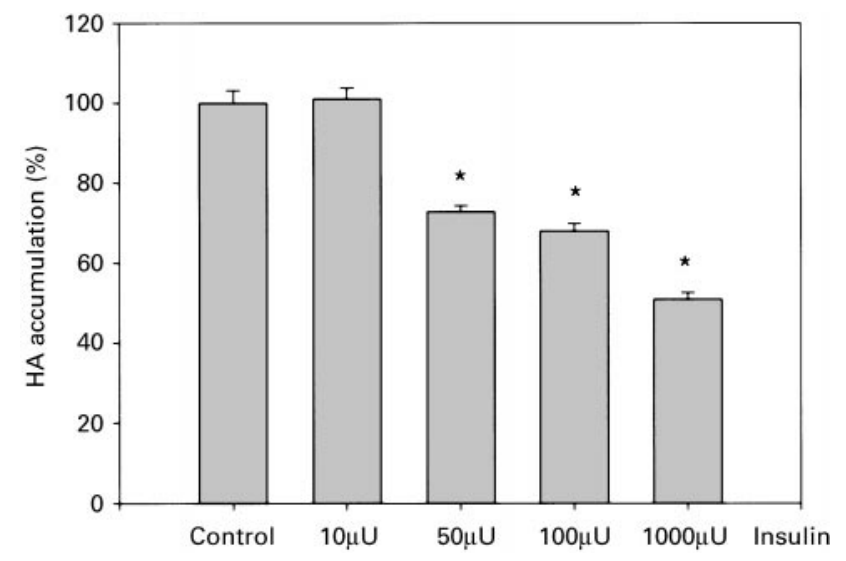

Figure 3 Effects of various doses of insulin on the accumulation of hyaluronan (HA) from human aortic smooth muscle cells in culture. Incubation time $36 \mathrm{~h}$. Values are means \pm S.E.M. Number of cultures $=10-12$. All insulin values are per $\mathrm{ml} .{ }^{\star} 2 P<0.01$.

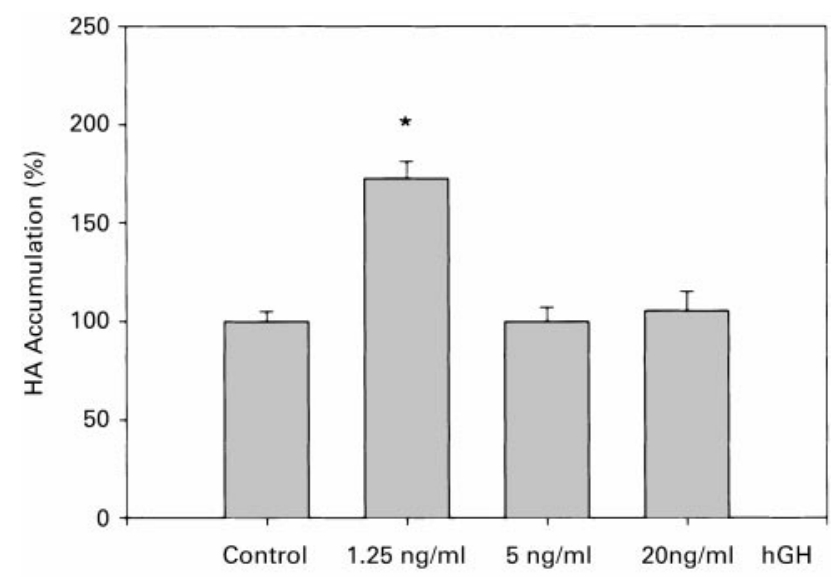

Figure 4 Influence of recombinant hGH on the accumulation of hyaluronan ( $\mathrm{HA})$ from cultures of human aortic smooth muscle cells over a period of $36 \mathrm{~h}$. Values are means \pm S.E.M. Number of cultures $=10-28 .{ }^{*} 2 P<0.01$. 


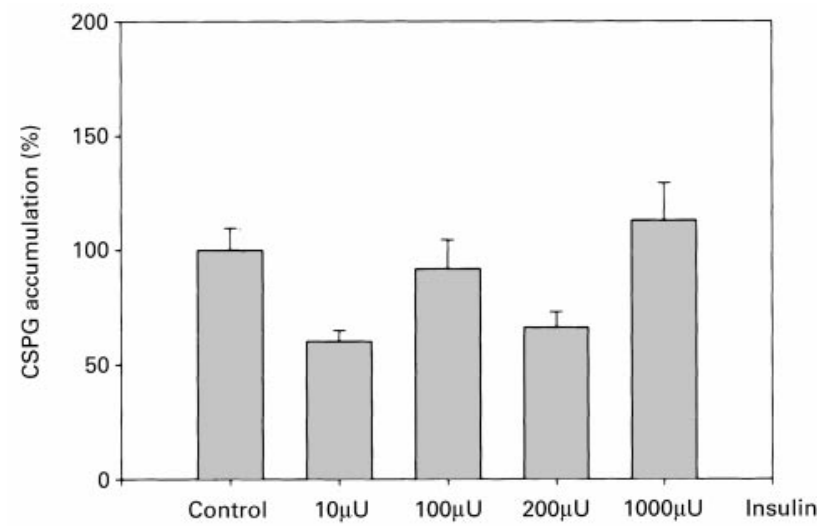

Figure 5 Accumulation of CSPG in human aortic smooth muscle cells in culture after exposure to graded doses of insulin. Cultures were incubated for $36 \mathrm{~h}$. Values are means \pm S.E.M. Number of cultures $=10-12$. All insulin values are per $\mathrm{ml}$.

\section{Discussion}

We found that glucose, insulin and hGH were able to change significantly the accumulation of either CSPG or hyaluronan from human arterial smooth muscle cells in culture. These observations have not been demonstrated previously.

As the experiments were performed in the presence of $5 \%$ serum, the production of proteoglycan may have been stimulated, to some degree, before the addition of test substances. However, in the incubation medium the concentrations of hGH, IGF-I, IGF binding proteins and insulin were $80 \%$ lower than those observed in undiluted serum. Therefore, the observed effects seem to be mainly due to the analysed substances (hGH, insulin, glucose, IGF-I) added to the cell culture medium.

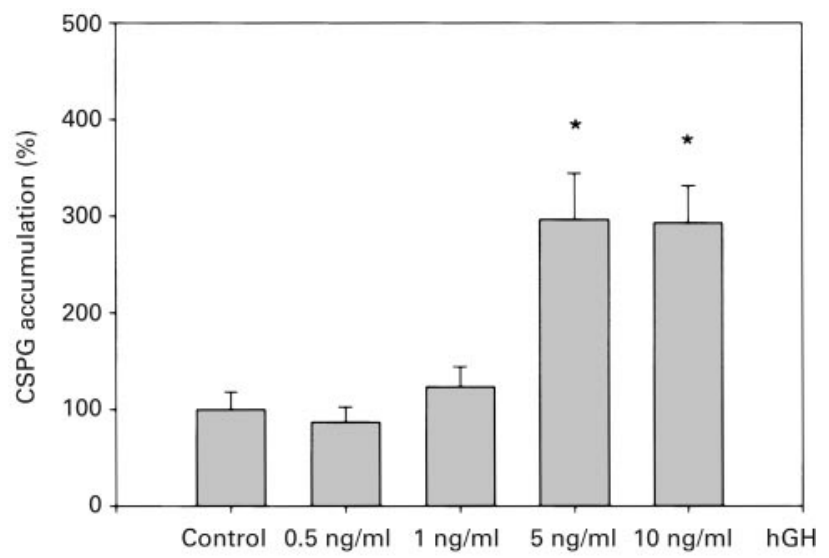

Figure 6 Effects of various doses of recombinant hGH on the accumulation of CSPG from cultures of human aortic smooth muscle cells. The cultures were incubated for $36 \mathrm{~h}$. Values are means \pm S.E.M. Number of cultures $=10-12 .{ }^{*} 2 P<0.01$.
High concentration of glucose reduced the accumulation of hyaluronan. Data obtained from in vitro studies have demonstrated that pooled serum from individuals with insulin-dependent diabetes mellitus stimulated the accumulation of hyaluronan in cultures of arterial smooth muscle cells (21). This observation may be of interest in relation to previous data from diabetic patients demonstrating increased concentrations of hyaluronan in areas of aorta without atherosclerosis (16). However, it is not clear which factor(s) causes this increase in hyaluronan in the vessel wall of diabetic patients. The present result does not support the idea that high glucose concentrations may be partly responsible for the greater amounts of hyaluronan. A similar conclusion was made in a study of non-treated rats with streptozotocin diabetes, which is a model of the effect of a constant, high concentrations of serum glucose (22). However, in another study a concentration of $25 \mathrm{mmol} / \mathrm{l}$ glucose significantly increased the production of hyaluronan from isolated glomerular cores from rats (23).

Insulin seems to reduce the concentration of hyaluronan, although previous in vitro studies have not been able to show any effect (21). However, these investigations were carried out in the presence of $15 \%$ serum, which may have blurred the effect of insulin. In vivo studies using insulin-treated rats with streptozotocin diabetes were not able to demonstrate any effect on the amount of hyaluronan in intima-media preparations from the aortas (22). Thus the present findings support the concept of insulin as a significant factor for the development of large-vessel disease in diabetes mellitus (24). However, this is not supported by previous data, although insulin receptor has been demonstrated in vascular smooth muscle cells (25).

It seems as if hGH in a concentration of $1 \mathrm{ng} / \mathrm{ml}$ stimulates the accumulation of hyaluronan. The reason for the lack of an effect of hGH in greater concentrations is unclear, as hGH receptors have been demonstrated in blood vessels (26). Consequently, the increased amount of hyaluronan in the vessel wall in diabetes seems not to be due to the increased serum hGH concentration.

The vascular smooth muscle cells express IGF-I receptor (27), but no effect of IGF-I was demonstrated. However, IGF binding proteins produced by the cells may interfere with the action of IGF-I $(28,29)$.

The present data show that glucose is able to increase the accumulation of CSPG in vitro at very high concentrations. This may be an effect of transforming growth factor (TGF)- $\beta$, as glucose can enhance the production of this peptide from the mesangial cells - a cell type related to smooth muscle cells (30). It has previously been demonstrated that TGF- $\beta$ is able to stimulate the production of CSPG from fibroblasts in vitro (31).

hGH stimulated the accumulation of CSPG in our in vitro system. However, some of this increase may have 
been due to the increased accumulation of the basement membrane material that occurs after hGH supplementation to cultures of arterial smooth muscle cells (32). This arterial basement membrane contains CSPG in the form of perlecan $(33,34)$. Furthermore, the alterations may also be confined to changes in the accumulation of biglycan and versican.

No effect of insulin on the production of CSPG was demonstrated in the present study. However, in vitro studies on pigs have shown an increase in the total amount of sulphated proteoglycans after the addition of insulin (35). It has been proposed that hyperinsulinaemia may have a deleterious effect on the vessel wall (24), but our data cannot support this view.

It is important to remember that these short-term investigations of the concentration of hyaluronan and CSPG were performed in cultures of human aortic smooth muscle cells. At present it would be inappropriate to extrapolate our findings directly to the situation prevailing in the large vessels of patients with long-term diabetes. Nevertheless, our findings, together with others - including, for example, the presence of increased plasma glucose, peripheral insulin and GH - suggest that aberrant diabetic metabolism per se may initiate the development of the diabetic macroangiopathy.

\section{Acknowledgements}

We wish to thank Ms Kirsten Hald (Department of Clinical Biochemistry) and Ms Merete Dixen (Laboratory for Biochemical Pathology) for technical assistance and Ms Karin Kristensen (Laboratory for Biochemical Pathology) for linguistic assistance. The present study was supported by the Danish Medical Research Council grant no. 9600822 (Aarhus University-Novo Nordisk Center for Research in Growth and Regeneration) and the Aarhus University Research Foundation, the Danish Heart Association, the Danish Diabetes Association, and the Dandy Foundation.

\section{References}

1 Iozzo RV. Matrix proteoglycans: from molecular design to cellular function. Annual Review of Biochemistry 199867 609-652.

2 Iozzo RV. The biology of the small leucine-rich proteoglycans. Functional network of interactive proteins. Journal of Biological Chemistry 1999274 18843-18846.

3 Savani RC, Wang C, Yang B, Zhang S, Kinsella MG, Wight TN et al. Migration of bovine aortic smooth muscle cells after wounding injury. The role of hyaluronan and RHAMM. Journal of Clinical Investigation 199595 1158-1168.

4 Nguyen L, Ward WF, Ts'ao CH \& Molteni A. Captopril inhibits proliferation of human lung fibroblasts in culture: a potential antifibrotic mechanism. Proceedings of the Society for Experimental Biology and Medicine 1994205 80-84.

5 West DC \& Kumar S. The effect of hyaluronate and its oligosaccharides on endothelial cell proliferation and monolayer integrity. Experimental Cell Research 1989183 179-196.

6 Schlessinger J, Lax I \& Lemmon M. Regulation of growth factor activation by proteoglycans: what is the role of the low affinity receptors? Cell $1995 \mathbf{8 3} 357-360$.
7 Kobayashi H \& Terao T. Hyaluronic acid-specific regulation of cytokines by human uterine fibroblasts. American Journal of Physiology 1997273 C1151-C1159.

8 Pentikainen MO, Lehtonen EM, Oorni K, Lusa S, Somerharju P, Jauhiainen $\mathrm{M}$ et al. Human arterial proteoglycans increase the rate of proteolytic fusion of low density lipoprotein particles. Journal of Biological Chemistry 1997272 25283-25288.

9 Lundbaek K. Blood vessel disease in diabetes mellitus. In Blood Vessel Disease in Diabetes Mellitus, pp 3-4. Eds K Lundbaek \& H Keen. Milano: 'Il Ponte' S.r.l., 1971.

10 Ledet T, Heickendorff L \& Rasmussen LM. Cellular mechanisms of diabetic large vessel disease. In International Textbook of Diabetes Mellitus, pp 1436-1446. Eds KGMM Alberti, RA DeFronzo, H Keen \& P Zimmet. London: John Wiley \& Sons Ltd, 1992.

11 Ledet T. Histological and histochemical changes in the coronary arteries of old diabetic patients. Diabetologia $19684268-272$.

12 Dybdahl H \& Ledet T. Diabetic macroangiopathy. Quantitative histopathological studies of the extramural coronary arteries from type 2 (non-insulin-dependent) diabetic patients. Diabetologia $198730882-886$.

13 Neubauer B \& Gundersen HJG. Calcifications, narrowing and rugosities of the leg arteries in diabetic patients. Acta Radiologica: Diagnosis 198324 401-413.

14 Rasmussen LM \& Heickendorff L. Accumulation of fibronectin in aortas from diabetic patients. A quantitative immunohistochemical and biochemical study. Laboratory Investigation 198961 440-446.

15 Rasmussen L \& Ledet T. Aortic collagen alterations in human diabetes mellitus. Changes in basement membrane collagen content and in the susceptibility of total collagen to cyanogen bromide solubilisation. Diabetologia 199336 445-453.

16 Heickendorff L, Ledet T \& Rasmussen LM. Glycosaminoglycans in the human aorta in diabetes mellitus: a study of tunica media from areas with and without atherosclerotic plaque. Diabetologia $199437286-292$.

17 Thogersen VB, Heickendorff L \& Ledet T. A quantitative method for analysis of radiolabelled proteoglycans synthesized by cultured human arterial smooth muscle cells. International Journal of Biochemistry 199426 55-59.

18 Rago R, Mitchen J \& Wilding G. DNA fluorimetric assay in 96 well tissue culture plates using Hoechst 33258 after cell lysis by freezing in distilled water. Analytical Biochemistry $199019131-$ 34.

19 Lowry OH, Rosebrough NJ, Faw LA \& Randall RJ. Protein measurement with the folin-phenol reagent. Journal of Biological Chemistry $1951 \mathbf{2 4 2} 1918-1922$.

20 Heinegard D \& Sommarin I. Isolation and characterization of proteoglycans. In Structural and Contractile Proteins, pp 319-372. Ed LW Cunningham. Orlando: Academic Press, 1987.

21 Jarvelainen H, Ronnemaa T \& Lehtonen A. Effect of sera from male type I (insulin-dependent) diabetics on human aortic smooth muscle cells in culture. Acta Endocrinologica 1987114 362-370.

22 Chajara A, Raoudi M, Delpech B, Courel M, Leroy M, Basuyau JP et al. Effects of diabetes and insulin treatment of diabetic rats on hyaluronan and hyaluronectin production in injured aorta. Journal of Vascular Research 199936 209-221.

23 Mahadevan P, Larkins RG, Fraser JR, Fosang AJ \& Dunlop ME. Increased hyaluronan production in the glomeruli from diabetic rats: a link between glucose-induced prostaglandin production and reduced sulphated proteoglycan. Diabetologia $199538298-$ 305.

24 Stout RW \& Vallance-Owen J. Insulin and atheroma. Lancet 1969 i $1078-1080$.

25 Obata T, Kashiwagi A, Maegawa H, Nishio Y, Ugi S, Hidaka H et al. Insulin signaling and its regulation of system $\mathrm{A}$ amino acid uptake in cultured rat vascular smooth muscle cells. Circulation Research 199679 1167-1176.

26 Simard M, Manthos H, Giaid A, Lefebvre Y \& Goodyer CG. Ontogeny of growth hormone receptors in human tissues: an 
immunohistochemical study. Journal of Clinical Endocrinology and Metabolism 199681 3097-3102.

27 Scheidegger KJ, James RW \& Delafontaine P. Differential effects of low density lipoproteins on insulin-like growth factor-I (IGF-I) and IGF-I receptor expression in vascular smooth muscle cells. Journal of Biological Chemistry 2000275 26864-26869.

28 Andersson P, Gustafsson T \& Arnqvist HJ. Insulin-like growth factor binding proteins- 2 to -6 are expressed by human vascular smooth muscle cells. Journal of Endocrinology $1999163281-$ 288.

29 Hayford K, Boes M, Dake BL \& Bar RS. Regulations of IGF binding proteins in human aorta vascular smooth muscle cells by cAMP, dexamethasone and IGF-I. Growth Hormone and IGF Research $19988369-375$.

30 Ishii $\mathrm{H}$, Tada $\mathrm{H} \&$ Isogai S. An aldose reductase inhibitor prevents glucose-induced increase in transforming growth factor-beta and protein kinase $\mathrm{C}$ activity in cultured mesangial cells. Diabetologia 199841 362-364.

31 Bassols A \& Massagué J. Transforming growth factor $\beta$ regulates the expression and structure of extracellular matrix chondroitin/ dermatan sulfate proteoglycans. Journal of Biological Chemistry 1988263 3039-3045.
32 Ledet T \& Heickendorff L. Growth hormone effect on accumulation of arterial basement membrane-like material studied on rabbit aortic myomedial cell cultures. Diabetologia 198528922 927.

33 Couchman JR, Kapoor R, Sthanam M \& Wu RR. Perlecan and basement membrane-chondroitin sulfate proteoglycan (bamacan) are two basement membrane chondroitin/dermatan sulfate proteoglycans in the Engelbreth-Holm-Swarm tumor matrix. Journal of Biological Chemistry 1996271 9595-9602.

34 Heickendorff L \& Ledet T. Glycosaminoglycans of arterial basement membrane-like material from cultured rabbit aortic myomedial cells. Biochimica et Biophysica Acta 1984798 276282.

35 Breton M, Berrou E, Deudon E, Brahimi Horn MC \& Picard J. Effect of insulin on sulfated proteoglycan synthesis in cultured smooth muscle cells from pig aorta. Experimental Cell Research $1988177212-220$.

Received 4 December 2000

Accepted 18 April 2001 